\title{
Phytomanagement of a Chromium-contaminated Soil by a High-value Plant: Phytostabilization of Heavy Metal Contaminated Sites
}

\author{
Li-Li Ye, ${ }^{a}$ Yong-Shan Chen, ${ }^{\text {, } *}$ Yu-Dao Chen, ${ }^{a}$ Lian-Wen Qian, ${ }^{\text {,c }}$ Wen-Li Xiong, ${ }^{b}$ \\ Jing-Hua $\mathrm{Xu},{ }^{b}$ and Jin-Ping Jiang ${ }^{\mathrm{a}, *}$
}

\begin{abstract}
Phytoremediation of metal-contaminated soil can be an eco-friendly technology. However, relatively long cultivation times impedes its popularization on a commercial scale. This study evaluated the effectiveness of lavender plants (Lavandula dentata L.) to remediate a highly chromium $(\mathrm{Cr})$-contaminated site through a pot experiment. The lavender growing soil was mixed both with and without biochar $(2.5 \% \mathrm{w} / \mathrm{w})$ + oyster shell waste $(2.5 \% \mathrm{w} / \mathrm{w})$ and biochar $(2.5 \% \mathrm{w} / \mathrm{w})+$ citrus peel waste $(2.5 \% \mathrm{w} / \mathrm{w})$. The results indicated that $\mathrm{Cr}(\mathrm{VI})$ accounted for $19.0 \%$ to $4.7 \%$ of the total soil $\mathrm{Cr}$, while $\mathrm{Cr}$ (III) accounted for $81.0 \%$ to $95.3 \%$, from the beginning to the end of the cultivation. The water-soluble $\mathrm{Cr}$ concentration decreased from $44.6 \mathrm{mg} / \mathrm{kg}$ to $7.5 \mathrm{mg} / \mathrm{kg}$. The biomass of the lavender growing in the contaminated soil decreased by factors in the range between 4-fold and 6-found.The addition of soil amendments significantly reduced the (potential) bioavailable $\operatorname{Cr}(p<0.05)$ in the range of 2 to 3 fold, consequently improving the growth of lavender in the highly toxic soil. In addition, the soil amendments significantly reduced the $\mathrm{Cr}$ bioaccumulation and the translocation from the roots to the shoots. These results showed that the cultivation of lavender with suitable amendments can effectively be used for phytomanagement techniques in highly contaminated soil.
\end{abstract}

Keywords: Chromium; Phytoremediation; Lavender; Biochar; Oyster shells

Contact information: a: Guangxi Key Laboratory of Environmental Pollution Control Theory and Technology, Guilin University of Technology, Guilin, China; $b$ : School of Resources and Environmental Science, Quanzhou Normal University, Quanzhou 362000 China; c: College of the Environment and Ecology, Xiamen University, Xiamen 361102 China;

*Corresponding author: yshchen421@163.com; jiangjinping74@163.com

\section{INTRODUCTION}

Soil contamination is a global problem with potential risks to human health and ecosystem stability (Carré et al. 2017). Pollutants in the food chain (e.g., soil-plant-human, soil-plant-animal-human, or contaminated ground water) adversely affect human health globally, with harmful effects on soil ecosystem services (Morel et al. 2015; Zhao et al. 2015; Arslan et al. 2016). The remediation of contaminated soils is crucial to reduce associated risks and to enhance food security (i.e., food quality and quantity). Soil remediation based on physico-chemical methods is generally expensive and often results in soil deterioration. Therefore, eco-friendly technologies, such as phytoremediation, have been developed (Ali et al. 2013; Ding et al. 2018).

Phytoremediation comprises bioremediation processes that use living green plants to remove, transfer, stabilize, and/or destroy contaminants in the soil. Such methods are 
widely evaluated as green and cost-effective environmental restoration technologies (Wang et al. 2018; Yang 2018). The principles of phytoremediation is to decrease the labile pool of contaminants and to reduce the pollutant linkages that are based on two main strategies, namely phytostabilization and phytoextraction. More than 500 plant species are highlighted as the most promising hyperaccumulators. Many phytoremediation studies have been performed in the last few decades, resulting in progressive research and the development of the phytotechnologies, including innovative approaches and paradigms (Agnello et al. 2014; Antoniadis et al. 2017). The advantages of phytoremediation (i.e., green technology and low costs) have led to high public acceptance; generally, these methods are considered aesthetically pleasing and environmental friendly management strategies for the remediation of contaminated soils (Ali et al. 2013; Sarwar et al. 2017). However, the limitations of phytoremediation, such as the long periods required for effective metal removal, particularly in moderately and highly contaminated sites, need to be considered (Conesa et al. 2012; Burges et al. 2018). Several factors, including plant life cycles (from planting or transplanting to harvesting, namely a growth season), low plant biomass and growth, along with bioavailability and bioaccessibility of metals and metalloids in the soil, can extend the removal period (Zayed and Terry 2003; Ali et al. 2013). Site characteristics, such as soil properties, mixed contamination, and climatic conditions, can also considerably affect the remediation efficiency (Mendez and Maier 2008). Agricultural activities, such as fertilization and field management, can enhance the growth of phytoremediation plants and therefore stimulate the remediation capacity (Chen and Cutright 2002; Wei et al. 2010; Tang et al. 2017). Technologies, such as the use of chelating agents, transgenic plants, and soil amendments, can also be suitable options to overcome the disadvantages (Evangelou et al. 2007; Yadav et al. 2009; Zhang et al. 2013). Generally, the strategies to increase phytoremediation efficiencies involve logistical difficulties in large-scale applications, mainly because of additional costs and potential environmental risks (e.g., leaching into the groundwater), hampering the deployment of such methods on commercial scales (Conesa et al. 2012; Mahar et al. 2016).

Chromium (Cr), particularly in its hexavalent form, is one of the widespread heavy metals that causes serious environmental problems in soil and groundwater (Ertani et al. 2017; Shahid et al. 2017). The trivalent (Cr(III)) and hexavalent ( $\mathrm{Cr}(\mathrm{VI})$ ) forms are the stable chemical forms found in the environment, with $\mathrm{Cr}(\mathrm{VI})$ causing the greatest concern because of its toxicity to all forms of life (Ertani et al. 2017). Additionally, $\mathrm{Cr}(\mathrm{VI})$ is more water-soluble and more mobile than $\mathrm{Cr}$ (III) in soil and therefore has a comparatively high soil-plant transfer index (Han et al. 2004; Shahid et al. 2017). Numerous studies have been conducted with several plant species to evaluate the phytoremediation of Cr-contaminated soils (Shahandeh and Hossner 2000; Sinha et al. 2018). These species include both native genotypes and agronomic species. For example, Portulaca oleracea (an annual, succulent herb) is considered a prospective plant for the phytoremediation of Cr-contaminated sites, and Zea mays L. shows high tolerance towards $\mathrm{Cr}$ with enhanced efficiency of $\mathrm{Cr}(\mathrm{VI})$ phytoextraction when amended with phosphate (Kale et al. 2015; Gheju and Balcu 2017). However, most of these plants require regular and precise management practices to promote the phytoremediation efficiency. As a result, sufficient financial support is crucial to establish the phytoremediation technology in the initial stage. In most parts of the world, funding for remediation projects, particularly for the rehabilitation of contaminated farmland is scarce ( $\mathrm{Qu}$ et al. 2016). Therefore, involving the public in soil remediation programs can be a viable alternative to mitigate soil pollution, particularly in remote and less developed regions (Conesa et al. 2012; Gupta et al. 2013). Such an approach represents 
an opportunity for the public to obtain economic benefits. Plant species that can provide financial returns (e.g., energy crops, cash crops, potential biochar sources, and medicinal plants) are currently being evaluated in phytomanagement studies (Pandey et al. 2016; Thijs et al. 2017; Venkatachalam et al. 2017; Verma et al. 2017). However, the relatively low economic benefits are still an obstacle for public involvement in the rehabilitation of contaminated areas. In this context, this study used lavender (Lavandula dentata L.) for the phytoremediation of a soil polluted with high levels of chromium. Lavender is not a hyperaccumulator. Rather, it is a commercially grown plant. Accordingly it ordinarily is not used for extracting chromium from soil, but for stable management of chromium pollutants in soil. Specifically, whether this high-value plant can be successfully cultivated in such a site was tested. The selection of this plant species was based on its use for producing an essential oil that is frequently used in soaps, detergents, and cosmetics. Studies have shown that the essential oils produced from plants in metal-contaminated soils are generally free of heavy metals (Zheljazkov et al. 2006; Gupta et al. 2013; Verma et al. 2017). Agricultural wastes (or their derived products), such as oyster shell waste, citrus peel waste, and biochar, are used as soil amendments to reduce the water-soluble fraction of $\mathrm{Cr}$, which has a strong relationship with soil phytotoxicity. Biochar is widely recommended as a cost-effective soil amendment for metal-contaminated soils because of its high sorption capability (Ahmad et al. 2014). Oyster shells (Crassostrea angulata) and citrus peels (Citrus maxima) are common agricultural wastes in the Fujian province of China and have become a serious environmental problem due to their local and random disposal. Oyster shell waste is particularly rich in $\mathrm{CaCO}_{3}$ and $\mathrm{CaO}$ components, which can serve as a liming material for the stabilization of metal-contaminated soil due to the formation of insoluble metal hydroxides at alkaline $\mathrm{pH}$ levels (Moon et al. 2013). Citrus peel waste was also considered as an efficient biosorbent in the removal of metal(loid)s from waste (Njikam and Schiewer 2012; Bhatti et al. 2016). So these agricultural wastes were added in chromium polluted soils to reduce $\mathrm{Cr}(\mathrm{VI})$ to $\mathrm{Cr}(\mathrm{III})$ for decreasing the toxicity to improve the lavender growth.

The aim of the present study was to reveal the effects of agricultural waste on the growth of lavender, the accumulation characteristics of chromium and the toxicity of chromium in soil, and to analyze the potential of lavender in the management of high chromium contaminated soil. The assumption in the study was based on lavender has relatively high biomass in high $\mathrm{Cr}$ concentration soil after adding agricultural wastes, which can be used to extract essential oil after harvest, and its residue can be burned to extract chromium or disposed as hazardous waste if it contained high $\mathrm{Cr}$.

\section{EXPERIMENTAL}

\section{Materials}

Soil collection

Soil samples were collected from a Cr-contaminated slag site at a depth of $0 \mathrm{~cm}$ to $20 \mathrm{~cm}$ from Qingdao in Eastern China, with an average Cr concentration of 8,700 mg/kg \pm $200 \mathrm{mg} / \mathrm{kg}$. Approximately 200,000 tons of chromite ore processing residues (COPRs) had been deposited at this contaminated site $\left(14,000 \mathrm{~m}^{2}\right)$ from 1959 to 2004 , generated from a chromate production enterprise. Due to the leaching of rainfall, chromium may dissolve into the leachate and cause serious soil pollution. After 2007, all the COPRs were safely removed, and no vegetation covers were found before soil sampling. The soil, classified as 
a fluvo-aquic soil, was characterized by a silty loam texture (with $77.6 \%$ silt, $15.3 \%$ sand, and $7.1 \%$ clay) with an average $\mathrm{pH}$ of $8.87 \pm 0.08$. The soil prior to the experiment contained $25.0 \mathrm{~g} / \mathrm{kg}$ of soil organic matter and $12.9 \mathrm{cmol} / \mathrm{kg}$ cation exchange capacity (CEC). Other contaminants, such as heavy metals, were below the safe limits in agricultural soil (see table $\mathrm{S} 1$ ). For example, the total $\mathrm{Ni}$ concentration in the studied soil ranged from $32.6 \mathrm{mg} / \mathrm{kg}$ to $33.1 \mathrm{mg} / \mathrm{kg}, \mathrm{Cu}(34.1 \mathrm{mg} / \mathrm{kg}-51.5 \mathrm{mg} / \mathrm{kg}), \mathrm{Zn}$ from $534.1 \mathrm{mg} / \mathrm{kg}$ to 654.0 $\mathrm{mg} / \mathrm{kg}$, and As from $29.7 \mathrm{mg} / \mathrm{kg}$ to $34.2 \mathrm{mg} / \mathrm{kg}$, respectively. Therefore, only Cr toxicity was considered during plant growth in this study. Soil samples were air-dried at room temperature and crushed to pass through a 2-mm sieve prior to the application of various soil amendments and to transplanting.

\section{Soil amendment preparation}

Biochar was produced in a muffle furnace with $\mathrm{N}_{2}$ flow, using rice straw combusted at $400{ }^{\circ} \mathrm{C}$ for approximately $4 \mathrm{~h}$. Before being mixed with the soil, the biochar was passed through a 2-mm stainless steel sieve. Oyster shell waste (Crassostrea angulata) was collected from a local oyster farm (Quanzhou City, China), crushed, and ground to pass through a $<0.3-\mathrm{mm}$ mesh. Citrus peel waste (Citrus maxima) was collected from a local fruit market (Quanzhou City, China) and was ground and sieved to a 1-mm to 1.1-mm diameter. The selection of these three bio-wastes was based on their local availability and their disposal's association with considerable environmental impacts. In addition, these three amendments were easily obtained locally at low costs.

\section{Pot experiment}

The greenhouse pot experiment was conducted to investigate the remediation efficiency of Lavandula dentata L. The experiment was performed in the greenhouse of Quanzhou Normal University in Fujian, China, using 12 foamed boxes $(80 \mathrm{~cm}$ length $\times 60$ $\mathrm{cm}$ width $\times 40 \mathrm{~cm}$ height). The following treatments were tested: (T1) contaminated soil amended and mixed with $2.5 \mathrm{wt} \%$ biochar and $2.5 \mathrm{wt} \%$ oyster shell waste; (T2) contaminated soil amended and mixed with $2.5 \mathrm{wt} \%$ oyster shell waste and $2.5 \mathrm{wt} \%$ citrus peel waste; (T3) contaminated soil without any amendments; and (T4) uncontaminated soil from a local (Quanzhou, China) agricultural farm, which was under more than $5 \mathrm{yr}$ of continuous cultivation of vegetables and free from heavy metal pollution (i.e., $<75.0 \mathrm{mg} / \mathrm{kg}$ $\mathrm{Cr})$.

After adding the amendments, the treated soils were subjected to a 1-week equilibrium period. The lavender (Lavandula dentata L.) seedlings used in this study were purchased from the Quanzhou Horticulture Company in Fujian, China. Healthy and uniform-sized seedlings with an average height of $4 \mathrm{~cm}$ were selected and transplanted into the three treatments (10 plants in each pot), with three replicates per treatment, following the same arrangement for each treatment. Prior to transplanting, each pot was fertilized with $120 \mathrm{~kg} \mathrm{~N} / \mathrm{ha}$ as $\mathrm{CO}\left(\mathrm{NH}_{2}\right)_{2}$ as well as $117 \mathrm{~kg} \mathrm{P} / \mathrm{ha}$ and $76.5 \mathrm{~kg} \mathrm{~K} / \mathrm{ha}$ as $\mathrm{KH}_{2} \mathrm{PO}_{4}$. The plants were grown under natural sunlight with a light/dark cycle of approximately $16 \mathrm{~h} / 8$ $\mathrm{h}$, and the temperature in the greenhouse was $18{ }^{\circ} \mathrm{C}$ to $30^{\circ} \mathrm{C}$. Each treatment was irrigated daily to maintain similar soil moisture values $(60 \%$ to $70 \%$ water holding capacity) in all treatments. The experiment was started on November 4, 2016, and lasted for $104 \mathrm{~d}$.

\section{Soil and plant sample collection}

Soil samples were taken at $0 \mathrm{~d}, 41 \mathrm{~d}$, and $104 \mathrm{~d}$ from each plot after transplanting. The soil was air-dried at room temperature, ground into $2-\mathrm{mm}$ and $0.15-\mathrm{mm}$ particles, and 
stored until analysis. After the cultivation, all plant roots and aerial parts (considered as shoots) in each pot were harvested, washed with tap water, rinsed with deionized water, and oven-dried at $60{ }^{\circ} \mathrm{C}$ to $70{ }^{\circ} \mathrm{C}$ for more than $48 \mathrm{~h}$. Subsequently, the plant biomass was determined, and the dried plant material was ground into a powder using mortar and pestle for chemical analysis.

\section{Methods}

\section{Chemical analysis}

Soil $\mathrm{pH}$ was measured in a 1:2.5 (w/v) mixture of soil and water with a $\mathrm{pH}-\mathrm{EC}$ meter (Excel XL60; Thermo Fisher Scientific, Waltham, MA, USA). The total Cr concentration of the dried samples was determined via microwave-assisted acid digestion, using trace-pure $\mathrm{HNO}_{3}$ and hydrofluoric acid (HF) and a closed-vessel, high-pressure microwave digester (Multiwave GO; Anton Paar, Graz, Austria). The digested solution was then quantitatively transferred to a sterile tube and diluted to volume with distilled water (containing $1.5 \% \mathrm{HNO}_{3}$, v/v). Standard solutions were prepared by dilution of 1,000 $\mathrm{mg} / \mathrm{L}$ stock solutions, and the calibration curve was obtained using seven points, including the blank. Inductively coupled plasma mass spectrometry (Agilent 7500cx; Agilent Technologies, Inc., Santa Clara, CA, USA) was applied to qualify and quantify the metal concentrations and the correlation coefficients $\left(\mathrm{r}^{2}=0.999\right.$ or better) of the linear calibration curves. The accuracy of the analysis methods was evaluated through repeated analysis of the standard reference materials (GBW07317 for soils and GBW007603 for plants obtained from the Center of National Standard Reference Material of China); recoveries of Cr were $106 \%$ and $91.7 \%$ for soil and plants, respectively. The laboratory control sample, the blank, and the duplicate samples (relative percent difference was less than 17\%) were prepared and analyzed as quality controls in each procedural batch.

Hexavalent chromium ( $\mathrm{Cr}(\mathrm{VI}))$ in the soil was extracted using the alkaline digestion method $\left(\mathrm{Na}_{2} \mathrm{CO}_{3} / \mathrm{NaOH}\right)$ according to USEPA Method 3060A (1996) and determined by colorimetry with diphenylcarbazide according to USEPA Method 7196A (1992). Trivalent chromium ( $\mathrm{Cr}(\mathrm{III})$ ) in the soil was calculated from total $\mathrm{Cr}$ and $\mathrm{Cr}(\mathrm{VI})$, for which it was assumed that the total $\mathrm{Cr}$ was composed of $\mathrm{Cr}$ (VI) plus $\mathrm{Cr}$ (III) (Banks et al. 2006). Modified Community Bureau of Reference (BCR) sequential extraction (F1: water-soluble fraction; F2: acid-soluble fraction; F3: reducible fraction; F4: oxidizable fraction; and F5: residual fractions) of the soil was conducted using the procedure of Arain et al. (2008). All extraction steps were performed in 50-mL polypropylene centrifuge tubes with screw caps. The detailed technical procedures for chemical fractionation can be found elsewhere (Tokalı̆ğlu et al. 2010; Hasan et al. 2018).

\section{Statistical analysis}

Statistical analysis was performed using SPSS 13.0 software for Windows (SPSS Inc., Chicago, IL, USA). One-way analysis of variance (ANOVA) and post hoc multiple comparisons (least significant difference) were used to determine the differences between treatments at a significance level of $\mathrm{p}<0.05$. The bioconcentration factor $(\mathrm{BCF})$ is an index to depict the ability of the plants to accumulate particular heavy metal from soil, and the translocation factor (TF) indicates the ability of plant to translocate the heavy metal from roots to the aerial part of plant (Mattina et al. 2003; Ghosh and Singh 2005). These are shown in Eqs. 1 and 2,

$$
B C F=\frac{C_{\mathrm{pt}}}{c_{\mathrm{s}}}
$$




$$
T F=\frac{c_{\mathrm{ap}}}{c_{\mathrm{r}}}
$$

where $c_{\mathrm{pt}}$ is the average metal concentration in the plant tissue $(\mathrm{mg} / \mathrm{kg}), c_{\mathrm{s}}$ is the metal concentration in the soil $(\mathrm{mg} / \mathrm{kg}), c_{\text {ap }}$ is the metal concentration in the aerial part of plant $(\mathrm{mg} / \mathrm{kg})$, and $c_{\mathrm{r}}$ is the metal concentration in the root of plant $(\mathrm{mg} / \mathrm{kg})$.

\section{RESULTS AND DISSCUSSION}

\section{Cr-contaminated Soils}

The studied soil was highly polluted with chromium, with $\mathrm{Cr}$ concentrations greater than $8,000 \mathrm{mg} / \mathrm{kg}$, which was 80 times greater than the natural background value of $\mathrm{Cr}$ in Qingdao, China (91 mg/kg to $108 \mathrm{mg} / \mathrm{kg}$ ) and much higher than the three-level standard of Soil Environmental Quality Standard in China (the recommendations for paddy fields and dry land areas are $500 \mathrm{mg} / \mathrm{kg}$ and $300 \mathrm{mg} / \mathrm{kg}$, respectively). Such soil should be carefully managed to prevent leaching and runoff. Based on the total $\mathrm{Cr}$ concentration and alkaline extraction, $\mathrm{Cr}(\mathrm{VI})$ accounted for at least $4.7 \%$ to $19.0 \%$ of the total soil $\mathrm{Cr}$, while $\mathrm{Cr}$ (III) accounted for $81.0 \%$ to $95.3 \%$, from the beginning to the end of the cultivation period, assuming that all the $\mathrm{Cr}$ (VI) was extracted by the alkaline digestion (James et al. 1995). It was noted that $\mathrm{CrO}_{4}{ }^{2-}$ and $\mathrm{HCrO}_{4}{ }^{-}$were the substantial species in $\mathrm{Cr}(\mathrm{VI})$ aqueous solutions and that the relative distribution of each varied with $\mathrm{pH}$, with $\mathrm{CrO}_{4}{ }^{2}$ being the dominant species in alkaline environments, thereby decreasing the diffusion of chromate ions in the soil environment due to the competitive adsorption between $\mathrm{OH}^{-}$ions and oxyanions of chromium (Sengupta et al. 1986; Mohamed et al. 2016). One reason for the decreased $\mathrm{Cr}(\mathrm{VI})$ concentration in the cultured soils (Fig. 1) might have been the high $\mathrm{pH}$ value (alkalinity) of the soil and the changed redox conditions following cultivation (Banks et al. 2006; Choppala et al. 2018).

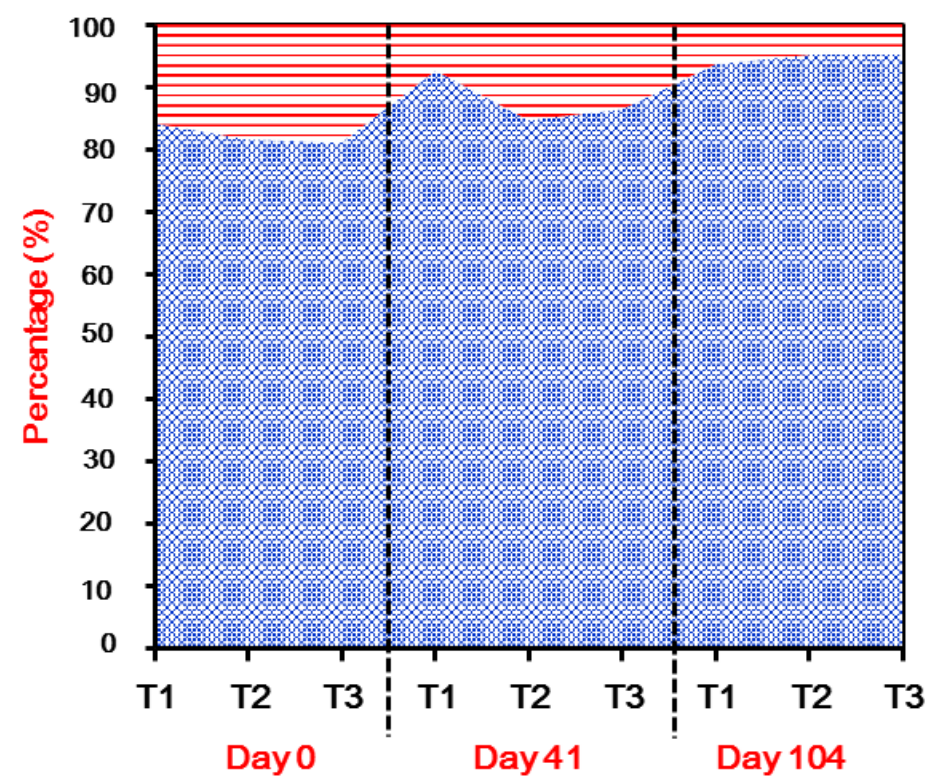

Fig. 1. The percentage of extracted $\mathrm{Cr}(\mathrm{VI})$ (the red part) and computed $\mathrm{Cr}$ (III) (blue part) in the soils depending on elapsed time - T1: contaminated soil was amended with $2.5 \mathrm{wt} \%$ biochar and $2.5 \mathrm{wt} \%$ oyster shell waste; T2: contaminated soil was amended with $2.5 \mathrm{wt} \%$ oyster shell waste and $2.5 \mathrm{wt} \%$ citrus peel waste; and T3: control soil without any amendments 
Throughout the entire cultivation period, the soil $\mathrm{pH}$ was rather alkaline (8.30 to 8.92), which increased the retention of $\mathrm{Cr}$ (III) because of the low solubility of $\mathrm{Cr}(\mathrm{OH})_{3}$ and $(\mathrm{Fe}, \mathrm{Cr})(\mathrm{OH})_{3}$ in the $\mathrm{pH}$ range of 7.0 to 9.0 (Rai et al. 1989). Under natural conditions, most of the $\mathrm{Cr}$ in soils is bound by iron oxides and organic matter, and only a small proportion occurs in the exchangeable form (Shahid et al. 2017). However, Cr(VI) mainly occurs as an anion, and its activities are controlled both by hydroxide minerals and organic matter in Cr-contaminated soils (Jardine et al. 2013; Hausladen and Fendorf 2017). Another reason may be that organic matter and biochar in the soil adsorb $\mathrm{Cr}$ (VI), some functional groups reacted with hexavalent chromium in the adsorption process (C-O was oxidized to $\mathrm{C}=\mathrm{O}$ ), which led to the reduction of $\mathrm{Cr}(\mathrm{VI})$ to $\mathrm{Cr}(\mathrm{III})$ (Yin et al. 2019).

Table 1 shows the chromium fractions in this study, where chromium was mainly associated with the residual phase. The water-soluble fraction (F1) showed Cr levels in the range of $5.0 \mathrm{mg} / \mathrm{kg}$ to $48.1 \mathrm{mg} / \mathrm{kg}$. The significant decrease of this $\mathrm{Cr}$ fraction (F1) in the contaminated soil during plant cultivation indicated effective remediation, including the amendments' sorption and plant uptake, which were likely based on the bioavailability of $\mathrm{Cr}$ in the aqueous phase.

The lower concentration of the F1 fraction in the T1 treatment (compared to T2 and T3) might be explained by the adsorption of water-soluble $\mathrm{Cr}$ to the biochar (Ahmad et al. 2014; Herath et al. 2017). Oyster shell waste also has a high sorption capacity for watersoluble metals, which probably led to the high concentration of the acid-soluble fraction (F2) in the T2 treatment (Table 1) (Moon et al. 2013). This fraction was predominantly extracted in the first step of the modified sequential extraction, representing the metal bound to acid-soluble fractions such as carbonates or sorbed/exchangeable phases (Arain et al. 2008).

Meanwhile, in all the treatments, the $\mathrm{Cr}$ levels in the leachate were related to the acid-soluble fraction, suggesting that the bioavailability of $\mathrm{Cr}$ (water-soluble fraction) in highly contaminated soil strongly depends on the sorbents and the soil pH (Zayed and Terry 2003; Kumpiene et al. 2008). Chromium extracted from the reducible phase accounted for $1,010 \mathrm{mg} / \mathrm{kg}$ to $1,832 \mathrm{mg} / \mathrm{kg}$. Alkaline soil conditions enhance the affinity of Fe/Al oxides to cations because of the high sorption capacity of Fe/Al hydroxides to metal elements (Langlois and James 2015).

In this study, alkaline $\mathrm{pH}$ values indicated the predominant negative charges on mineral surfaces, which would lead to appreciable electrostatic repulsion of the chromate oxyanions (He and Traina 2005; Gu et al. 2017). However, it was also noted that $\mathrm{Cr}(\mathrm{VI})$ would be firmly retained by $\mathrm{Fe}(\mathrm{III}) / \mathrm{Cr}$ (III) hydroxides, likely due to the formation of surface precipitates or complexes between $\mathrm{Cr}(\mathrm{VI})$ and $\mathrm{Cr}(\mathrm{III})$ sites, which could hardly be substituted by $\mathrm{OH}^{-}$during the $\mathrm{pH}$ increase (Tzou et al. 2003). The range of extractable $\mathrm{Cr}$ in the oxidizable fractions was $1,147 \mathrm{mg} / \mathrm{kg}$ to $1,830 \mathrm{mg} / \mathrm{kg}$, depending on the treatment, which showed increased concentration of this element in the soil, particularly in the T2 treatment that was amended with citrus peel waste. Organic matter can play a crucial role in $\mathrm{Cr}$ retention in the soil environment, because of the strong interaction with $\mathrm{Cr}$ (III), and in its ability to transform Cr(VI) to Cr(III) (Rai et al. 1989; Gustafsson et al. 2014). In addition, the low variability of the three main $\mathrm{Cr}$ fractions (i.e., reducible, oxidizable, and residual) during plant cultivation suggests a relatively successful stabilization of $\mathrm{Cr}$ due to the soil amendments. 
Table 1. Sequential Extractable $\mathrm{Cr}$ Concentrations in the Experimental Soils

\begin{tabular}{|c|c|c|c|c|c|c|c|}
\hline & & Water-soluble Fraction & Acid-soluble Fraction & Reducible Fraction & Oxidizable Fraction & Residual Fraction & Total Cr \\
\hline \multirow{4}{*}{ T1 } & Day 0 & $23.7 \pm 1.5^{\mathrm{a}}$ & $35.2 \pm 4.5^{\mathrm{a}}$ & $1,315.8 \pm 150.6^{\mathrm{a}}$ & $1,444.6 \pm 96.8^{\mathrm{a}}$ & $5,105.5 \pm 117.1^{\mathrm{ab}}$ & $7,924.7 \pm 365.7^{\mathrm{a}}$ \\
\cline { 2 - 8 } & Day 41 & $14.6 \pm 1.6^{\mathrm{b}}$ & $23.9 \pm 1.1^{\mathrm{b}}$ & $1,142.8 \pm 119.9^{\mathrm{a}}$ & $1,302.8 \pm 138.2^{\mathrm{a}}$ & $4,884.9 \pm 189.9^{\mathrm{a}}$ & $7,368.8 \pm 139.7^{\mathrm{b}}$ \\
\cline { 2 - 8 } & Day 104 & $7.5 \pm 2.2^{\mathrm{c}}$ & $20.6 \pm 2.8^{\mathrm{b}}$ & $1,098.3 \pm 148.2^{\mathrm{a}}$ & $1,280.7 \pm 155.3^{\mathrm{a}}$ & $5,254.9 \pm 170.6^{\mathrm{b}}$ & $7,662.0 \pm 85.2^{\mathrm{ab}}$ \\
\hline \multirow{3}{*}{ T2 } & Day 0 & $32.1 \pm 2.6^{\mathrm{a}}$ & $46.9 \pm 5.0^{\mathrm{a}}$ & $1,456.8 \pm 122.0^{\mathrm{a}}$ & $1,752.2 \pm 89.7^{\mathrm{a}}$ & $5,112.5 \pm 251.7^{\mathrm{a}}$ & $8,400.5 \pm 126.4^{\mathrm{a}}$ \\
\cline { 2 - 8 } & Day 41 & $24.8 \pm 1.5^{\mathrm{b}}$ & $33.9 \pm 0.6^{\mathrm{b}}$ & $1,287.0 \pm 97.9^{\mathrm{a}}$ & $1,462.2 \pm 72.5^{\mathrm{b}}$ & $4,861.1 \pm 147.8^{\mathrm{a}}$ & $7,669.0 \pm 8.7^{\mathrm{b}}$ \\
\cline { 2 - 8 } & Day 104 & $19.9 \pm 2.0^{\mathrm{c}}$ & $40.8 \pm 0.2^{\mathrm{c}}$ & $1,229.3 \pm 59.2^{\mathrm{a}}$ & $1,387.0 \pm 95.6^{\mathrm{b}}$ & $5,202.7 \pm 212.8^{\mathrm{a}}$ & $7,949.6 \pm 177.0^{\mathrm{c}}$ \\
\hline \multirow{3}{*}{ T3 } & Day 0 & $44.6 \pm 4.1^{\mathrm{a}}$ & $28.2 \pm 1.6^{\mathrm{a}}$ & $1,735.8 \pm 89.4^{\mathrm{a}}$ & $1,713.5 \pm 73.8^{\mathrm{a}}$ & $5,218.6 \pm 129.3^{\mathrm{a}}$ & $8,740.7 \pm 264.0^{\mathrm{a}}$ \\
\cline { 2 - 9 } & Day 41 & $33.1 \pm 2.9^{\mathrm{b}}$ & $24.1 \pm 3.0^{\mathrm{a}}$ & $1,335.3 \pm 121.6^{\mathrm{b}}$ & $1,441.7 \pm 121.1^{\mathrm{b}}$ & $5,354.1 \pm 230.1^{\mathrm{a}}$ & $8,178.4 \pm 179.7^{\mathrm{b}}$ \\
\cline { 2 - 9 } & Day 104 & $33.9 \pm 3.4^{\mathrm{b}}$ & $25.5 \pm 3.0^{\mathrm{a}}$ & $1,501.0 \pm 21.7^{\mathrm{b}}$ & $1,425.1 \pm 43.7^{\mathrm{b}}$ & $5,529.5 \pm 106.1^{\mathrm{a}}$ & $8,515.1 \pm 121.8^{\mathrm{b}}$ \\
\hline
\end{tabular}

Values represent mean \pm standard deviation (SD) (mg/kg dry mass). Different letters (a, b, c) represent significant differences (p<0.05) among sampling days in each treatment. T1: contaminated soil was amended with $2.5 \mathrm{wt} \%$ biochar and $2.5 \mathrm{wt} \%$ oyster shell waste; T2: contaminated soil was amended with 2.5 wt\% oyster shell waste and 2.5 wt\% citrus peel waste; and T3: control soil without any amendments 


\section{Growth of Lavender Plant}

Chromium significantly inhibited plant development (Fig. 2A), which was probably due to the toxic effects of $\mathrm{Cr}$ and the high bioavailability of the element in contaminated soils (Shahid et al. 2017; Velez et al. 2017). Here, the soil amendment combined with biochar and oyster shell waste (T2) reduced the toxic effects on the lavender. Plants growing in the untreated contaminated soil showed a decrease in shoot and root dry weight (DW) yields of more than $80 \%$ (compared with uncontaminated soil) (Fig. 2B), demonstrating a severe phytotoxicity that might be related to $\mathrm{Cr}$ excess greater than $8,000 \mathrm{mg} / \mathrm{kg}$. It has been reported that a level of $\mathrm{Cr}>5.2 \mathrm{mg} / \mathrm{kg}$ in soil can induce toxicity in plants such as Helianthus annuus (Davies Jr. et al. 2002). However, the stress effects on plant growth depend on a variety of soil conditions, such as $\mathrm{pH}$, organic matter, and oxidation-reduction potential (Nirola et al. 2018). In general, the $\mathrm{Cr}(\mathrm{VI})$ forms of chromate and dichromate are highly soluble in water, while $\mathrm{Cr}(\mathrm{III})$ is less soluble due to higher mobility of $\mathrm{Cr}(\mathrm{VI})$ in the soil environment. Several studies have evaluated the phytotoxicity of both $\mathrm{Cr}(\mathrm{III})$ and $\mathrm{Cr}(\mathrm{VI})$ in many plants with greater and lower biomasses, and found that $\mathrm{Cr}(\mathrm{VI})$ is more phytotoxic than $\mathrm{Cr}(\mathrm{III})$, particularly in retarding plant growth (Panda and Choudhury 2005). In this study, lavender growth was significantly affected by $\mathrm{Cr}$ at concentrations greater than $8,000 \mathrm{mg} / \mathrm{kg}$, which might have been mainly due to the excess $1,400 \mathrm{mg} / \mathrm{kg} \mathrm{Cr}(\mathrm{VI})$ in the initial stage. Similar results in previous studies also demonstrated a linear decrease in shoot and root dry weight resulting from increasing $\mathrm{Cr}(\mathrm{VI})$ concentrations (Velez et al. 2017). However, the reduction in plant growth is not only a factor of metal concentration, but it also depends on the chemical forms, which can play a crucial role in the heavy metal detoxification mechanisms (Ali et al. 2004). Previous research has shown that binding effects (i.e., metals binding to oxalates and residuals) can reduce the metals' toxicity to terrestrial plants (Clemens et al. 2002). Therefore, the application of soil amendments (i.e., biochar, oyster shells, and citrus peel waste) in this study could provide more sorption sites for $\mathrm{Cr}$ binding and consequently mitigate retardation of plant growth. In addition, none of the plants died during cultivation, indicating the stress tolerance of the lavender plants to $\mathrm{Cr}$ contamination.
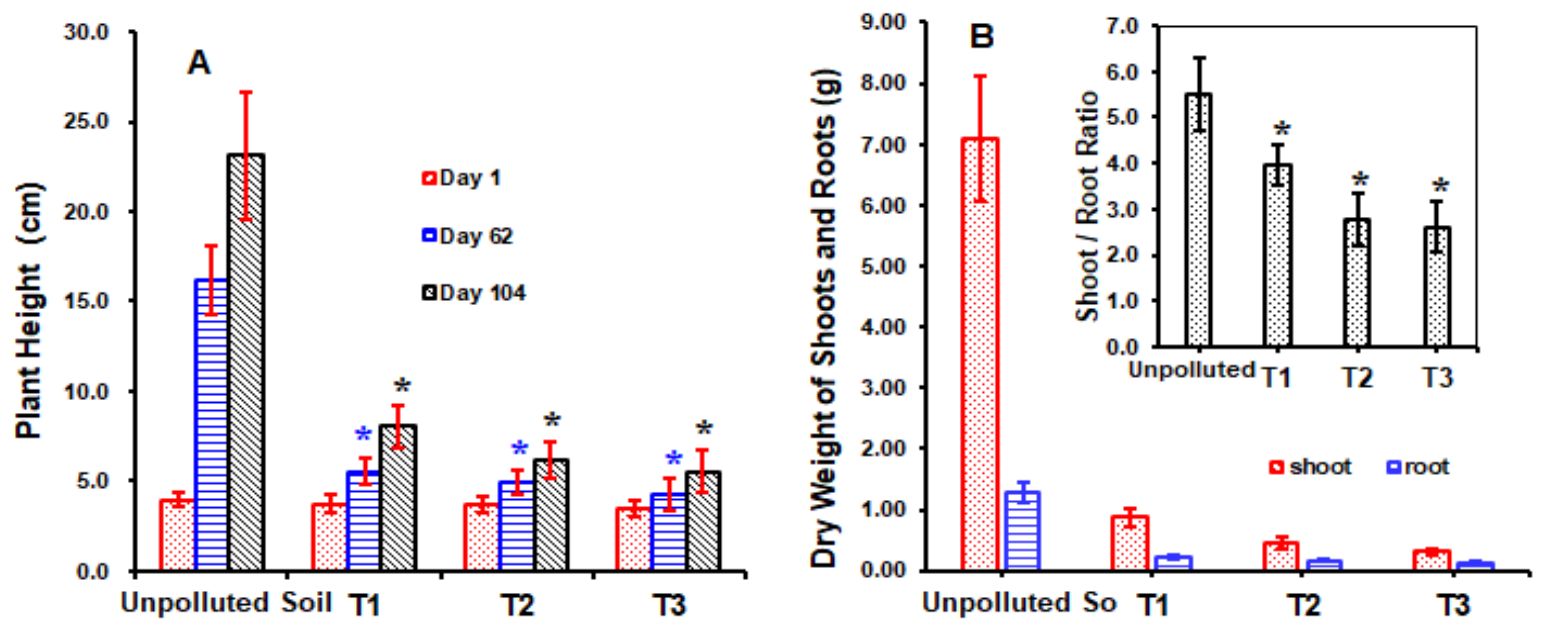

Fig. 2. A: Growth performance of lavender (Lavandula dentata L.) planted in soil with and without high concentrations of $\mathrm{Cr}$. B: Dry biomass weight was determined at the end of the experiment. Asterisks $\left(^{*}\right)$ indicate statistically significant differences with respect to control plants grown without $\operatorname{Cr}(\mathrm{p}<0.05)$. 
To investigate the phytomanagement potential of lavender plants in soils to total $\mathrm{Cr}$ concentrations, the cost-effective biosorbents biochar, oyster shell waste, and citrus peel waste were combined as soil amendments because of their high capacities to directly or indirectly react with heavy metals in the soil environment, thereby reducing metal bioavailability (Njikam and Schiewer 2012; Ahmad et al. 2014). After the incorporation of the soil amendments, the water-solution $\mathrm{Cr}$ fraction decreased almost 2 fold for the $\mathrm{T} 1$ treatment and 3 fold for T2 treatment (Table 1). In the un-amended soil, although plant growth was completely inhibited, the water-solution $\mathrm{Cr}$ fraction in the soil decreased $23.9 \%$, which might have been because lavender plants (shoots and roots) bioaccumulate $\mathrm{Cr}$. The total amounts of $\mathrm{Cr}$ uptake by the lavender plants (all plants in a pot, including shoots and roots) were approximately $2.82 \mathrm{mg} \mathrm{Cr}, 3.14 \mathrm{mg} \mathrm{Cr}$, and $3.59 \mathrm{mg} \mathrm{Cr}$ for the T1, $\mathrm{T} 2$, and $\mathrm{T} 3$ treatments, respectively. This concentration removal of $\mathrm{Cr}$ from contaminated soil accounted for $0.87 \%$ to $1.67 \%$ of the decrease of the water-solution $\mathrm{Cr}$ fraction, indicating the significant binding effects of soluble $\mathrm{Cr}$ with amendments and soil minerals (i.e., metals binding to residuals). The addition of amendments resulted in a significant reduction $(\mathrm{p}<0.05)$ in the water-soluble $\mathrm{Cr}$ fraction, which was more obvious with the biochar treatment (Table 1). The interaction of water-soluble $\mathrm{Cr}$ with amendments is controlled by a variety of factors, such as ion composition, metal species, and the charge on the sorptive surface, which are strongly influenced by $\mathrm{pH}$ levels (Egene et al. 2018; Wang et al. 2018). The significant decrease of this fraction indicates the sorption capacity of the selected materials (Njikam and Schiewer 2012; Moon et al. 2013; Ahmad et al. 2014). For example, shell waste showed its sorption capacity of arsenic and was shown to have positive effects on soil arsenic retention, while citrus peel waste was also considered as an efficient biosorbent in the removal of metal(loid)s from waste (Njikam and Schiewer 2012; Seco-Reigosa et al. 2013; Bhatti et al. 2016). The results suggested that these costeffective soil amendments can be used to improve the phytomanagement efficiency of high-value plants, such as lavender, and they represent an incentive for farmers to become actively involved in soil remediation projects due to the high-value returns (e.g., essential oil) with low input (i.e., cheap amendments) (Hashemi et al. 2017).

\section{Phytomanagement Efficiency of Lavender}

Figure 3 shows the bioaccumulation of $\mathrm{Cr}$ in the roots and shoots of the lavender plants. The treatments with soil amendments resulted in low $\mathrm{Cr}$ concentrations in the plant tissues. In contrast, the un-amended soil (T3) led to high $\mathrm{Cr}$ concentrations ( $\mathrm{mg} / \mathrm{kg} \mathrm{DW}$ ) in roots $(817.5 \pm 52.1)$ and shoots $(843.9 \pm 47.0)$ as compared to the $\mathrm{T} 1$ and $\mathrm{T} 2$ treatments (184.6 \pm 42.7 and $235.4 \pm 43.3$ for $\mathrm{T} 1 ; 631.5 \pm 75.4$ and $450.3 \pm 58.8$ for $\mathrm{T} 2$, respectively). However, the balance masses of $\mathrm{Cr}$ removal by the plants (sum of shoots and roots) were only $0.87 \% \pm 0.13 \%, 1.29 \% \pm 0.16 \%$, and $1.68 \% \pm 0.10 \%$ of total dissipated amounts of soil water-soluble $\mathrm{Cr}$ for $\mathrm{T} 1$ (323.3 mg Cr $\pm 42.6 \mathrm{mg} \mathrm{Cr}$ ), T2 (243.9 mg Cr $\pm 28.7 \mathrm{mg} \mathrm{Cr}$ ), and T3 (214.2 $\mathrm{mg} \mathrm{Cr} \pm 22.1 \mathrm{mg} \mathrm{Cr}$ ), respectively. These results demonstrated that $\mathrm{Cr}$ uptake by the lavender was significantly controlled by its bioavailability, such as the watersoluble fraction in the soil, which was reduced by the application of soil amendments, particularly in the treatment with biochar combined with oyster shell waste (Table 1). In general, the accumulation and distribution of metal(loid)s in plant tissues are important aspects to evaluate the role of plants in the remediation of metalliferous soils (Pichtel and Bradway 2008). In terms of removing metals from contaminated sites, a greater metal concentration in the aboveground parts is preferred for enhancing the phytoremediation efficiency (Ma et al. 2016). The high Cr concentrations in the lavender shoots $(843.9 \mathrm{mg} / \mathrm{kg}$ 
$\pm 47.0 \mathrm{mg} / \mathrm{kg}$ ) grown in highly Cr-contaminated soils were close to the threshold concentration of $\mathrm{Cr}$ hyperaccumulators $(1,000 \mathrm{mg} / \mathrm{kg}$ ) (Baker and Brooks 1989). The results demonstrate that the lavender plant could be considered as a potential hyperaccumulator in $\mathrm{Cr}$-contaminated sites, with the high toxicity of $\mathrm{Cr}$ to plants resulting in a rare ideal option for $\mathrm{Cr}$ phytoremediation (Nirola et al. 2018). However, the low plant yield and low growth rate of lavender in such highly $\mathrm{Cr}$-contaminated soil may restrict its phytoremediation efficiency. However, as a high-value plant, lavender is usually grown as a landscape plant and harvested to produce essential oil, which tends to be free from heavy metals. These financial returns from lavender growth may stimulate public involvement in the rehabilitation and management of contaminated farmland, particularly in remote and less developed regions. Therefore, lavender cultivation, combined with the suitable application of soil amendments, is a novel option to phytomanage highly Cr-contaminated soils.
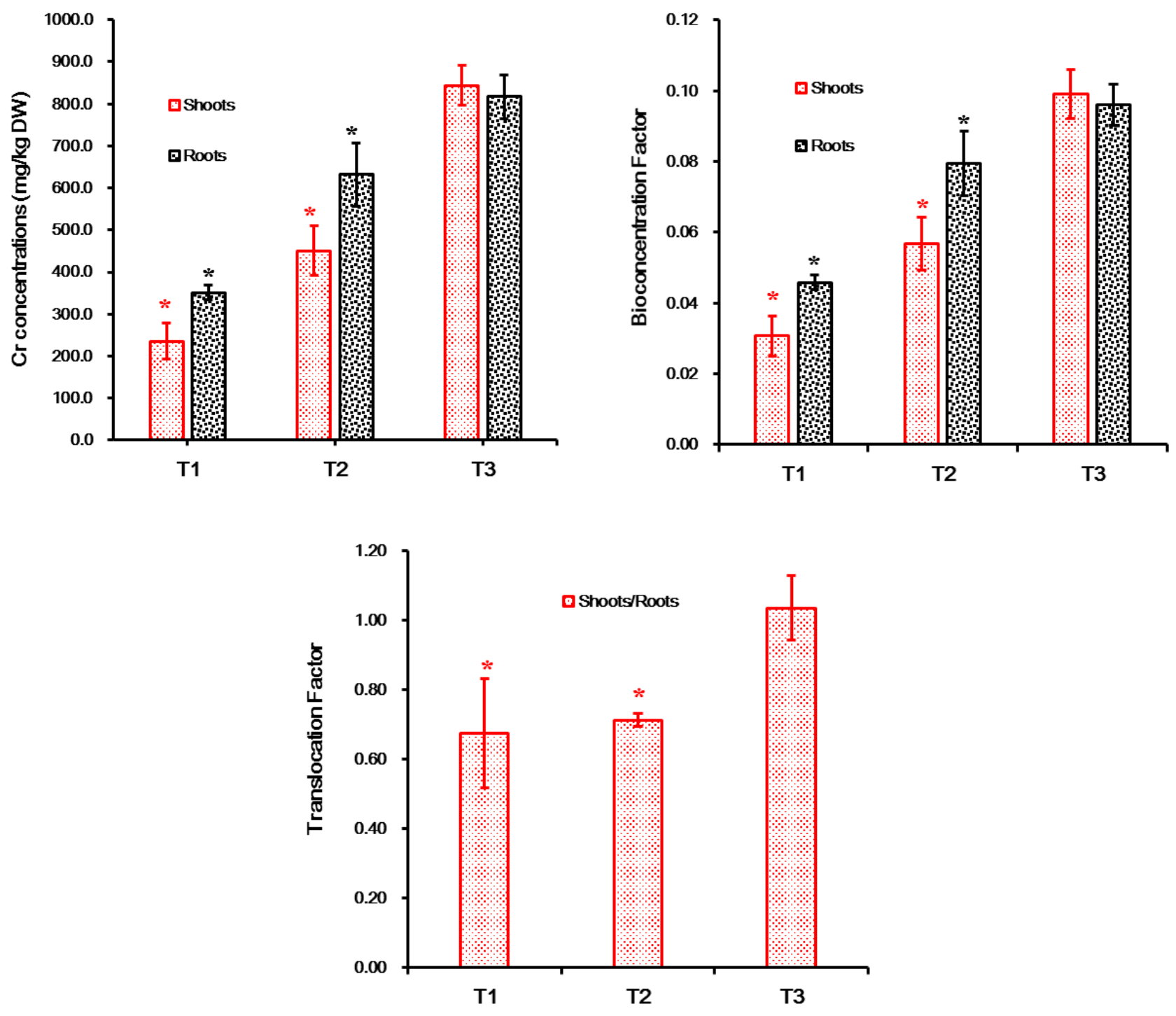

Fig. 3. Bioaccumulation and bioconcentration of lavender (Lavandula dentata L.) planted in soil with and without high soil amendments. Asterisks $\left(^{*}\right)$ indicate statistically significant differences with respect to the treatment without any amendments $(p<0.05)$. 
The BCF represents the capacity of a plant to accumulate elements such as metals. In this study, the BCF values of plants grown in un-amended metal-contaminated soil (T3) were significantly greater than those of plants grown in amended soils. Moreover, the BCF values became significantly decreased as a result of the increasing sorption capacity (i.e., biochar $v s$. citrus peel waste) of the amendments (Fig. 3).

The concentrations of water-soluble $\mathrm{Cr}$ were directly proportional to the metal bioconcentration factors of the plants (Fig. 4), suggesting that the application of amendments stabilized the heavy metals in the soil and reduced the bioavailable fraction of $\mathrm{Cr}$. The TF of the $\mathrm{Cr}$ from the lavender roots to the shoots was greater in plants grown in un-amended soil. Reductions in the root-to-shoot translocation of heavy metals in the plant after the addition of soil amendments have been previously reported and are most likely a result of altered metal speciation in the solution, which changes the phytoavailability by increasing the soil $\mathrm{pH}$ or influencing plant growth and plant physiology (Clemens et al. 2002; Yadav et al. 2009; Shahid et al. 2014; Vargas et al. 2016; Hashemi et al. 2017). Whenever phytostabilization or phytoextraction are chosen as a remediation technique, the risk of pollutant dispersal into the environment should be minimized. In addition, it has been suggested to cultivate non-food crops on metalcontaminated soils (e.g., aromatic plants) that can be used to produce essential oils (Gupta et al. 2013; Verma et al. 2017).

The percentage of heavy metal translocation to the harvestable parts is an important feature for the selection of a phytoremediation plant. However, in many $\mathrm{Cr}$ hyperaccumulators, native species from Cr-contaminated sites are frequently of low productivity and growth rate, which restricts their commercial use (Kale et al. 2015). The crops, such as Zea mays, must carefully consider the security of the food chain, thus reducing their application in open areas (Gheju and Balcu 2017). For lavender, although metal accumulation was observed in shoots, the essential oil is free from heavy metals. In addition, lavender plants can be cultivated as attractive ornamental elements on abandoned fields and cannot be damaged or eaten by wild animals due to its essential oil (Gupta et al. 2013). Therefore, lavender growth can offer a feasible alternative for the management of highly Cr-contaminated sites, especially where financial support to establish a remediation technology is not available (Zheljazkov et al. 2006).

Biochar and other agricultural wastes could absorb chromium ions and combine with them through porous filtration, ion exchange, electrostatic attraction and complexation reaction (Yin et al. 2019), which can prevent the migration and leakage of chromium ions in the soil and reduce the risk of chromium ion pollution to groundwater and surface water. In fact, lavender is a perennial plant.

In order to improve the remediation efficiency of polluted soil, the aboveground part and the underground part should be harvested together in slightly or moderately chromium contaminated soil, because the root system of lavender is developed and contains high content of chromium. However, it may be recommended to harvest only the above ground part in an area with serious soil erosion or in the soil seriously polluted by chromium, because the strong root system of lavender is conducive to prevent the diffusion of pollutants with the surface runoff. After the extraction of essential oil, lavender residues should be burned and disposed of safely as hazardous waste because they contained high concentrations of chromium (Lu et al. 2012). 


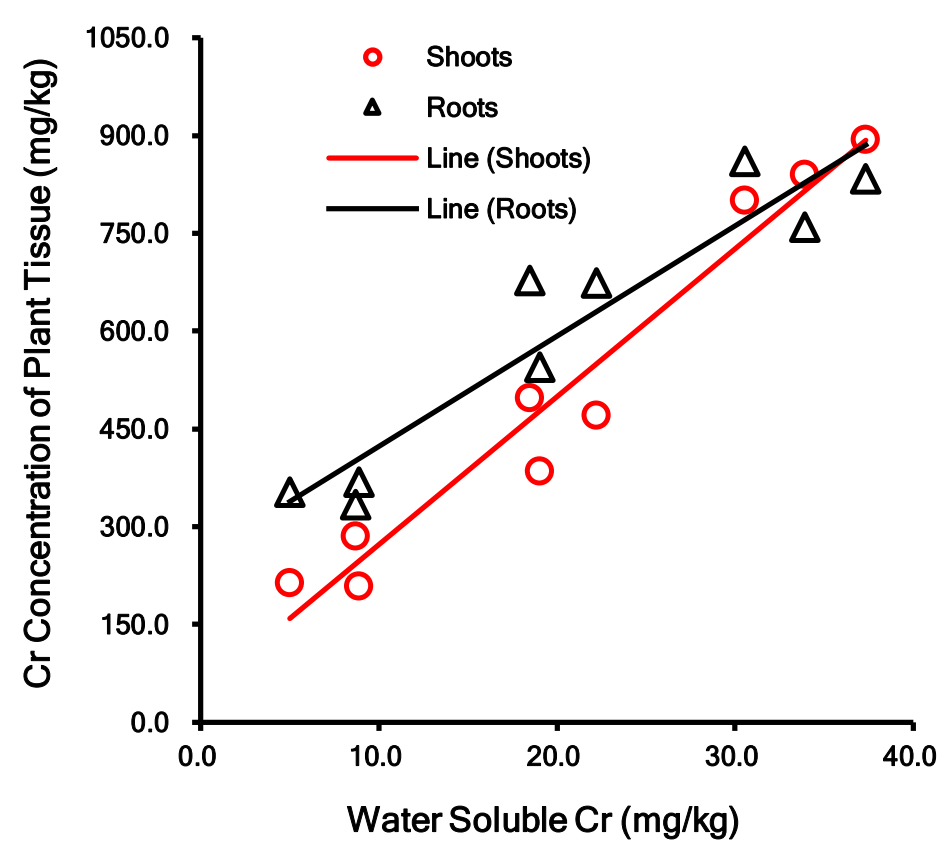

Fig. 4. Relationship between $\mathrm{Cr}$ concentration in the plant tissue (shoots and roots) and the concentration of the water-soluble Cr fraction

\section{CONCLUSIONS}

1. High $\mathrm{Cr}$ concentration (greater than $8,000 \mathrm{mg} / \mathrm{kg}$ ) in the soil affected the lavender plants' growth by significantly decreasing plant height and biomass. The high proportion of $\mathrm{Cr}(\mathrm{VI})$ of total soil $\mathrm{Cr}$ in the initial stage was the main reason for these inhibitions.

2. Soil amendments, including biochar $(2.5 \mathrm{wt} \%)+$ oyster shell waste $(2.5 \mathrm{wt} \%)$ and oyster shell waste $(2.5 \mathrm{wt} \%)+$ citrus peel waste $(2.5 \mathrm{wt} \%)$, reduced the water-soluble soil $\mathrm{Cr}$ fraction and thereby impeded the $\mathrm{Cr}$ uptake by the plants. As a result, the growth of the lavender plants was significantly enhanced via the additions of the soil amendments, particularly in the treatment combining biochar with oyster shell waste. So biochar, oyster and citrus peel wastes were good soil amendments to improve phytoremediation plant growth in sever $\mathrm{Cr}$ polluted soil.

3. In addition, the relatively high $\mathrm{Cr}$ concentrations in the lavender shoots (up to 843.9 $\mathrm{mg} / \mathrm{kg} \pm 47.0 \mathrm{mg} / \mathrm{kg}$ ) and roots (up to $817.5 \mathrm{mg} / \mathrm{kg} \pm 52.1 \mathrm{mg} / \mathrm{kg}$ ) in un-amended soil suggested lavender was a chromium tolerant plant and it could be used for phytomanagement of $\mathrm{Cr}$ serious polluted soil. Based on its special uses (i.e., as an essential oil), lavender (Lavandula dentata $\mathrm{L}$.) represented a prospective plant for the phytoremediation of Cr-contaminated soils, and its biomass could be enhanced with the addition of soil amendments. Such an approach combines economic viability with the low risk of metal accumulation in the plant biomass. In the process of lavender stabilization management of high concentration chromium contaminated soil, it is recommended to harvest only the above ground part of lavender for essential oil extraction, and the residue should be disposed according to the hazardous waste management method after incineration. 


\section{ACKNOWLEDGMENTS}

This work was supported by the National Natural Science Foundation of China (Grant Nos. 41671495 and 41661097), the Agricultural Guidance Project of Fujian Provincial Science and Technology Department (Grant Nos. 2018N0028 and 2015N0033), and the Program for New Century Excellent Talents in Fujian Province University. The authors thank Dr. Yongqiang Yuan from the Institute of Urban Environment, Chinese Academy of Sciences, for his kind help with the chromium chemical analysis procedure. The authors also thank Dr. Asfandyar Shahab for his kind help in editing the language.

\section{REFERENCES CITED}

Agnello, A. C., Huguenot, D., Van Hullebusch, E. D., and Esposito, G. (2014).

"Enhanced phytoremediation: A review of low molecular weight organic acids and surfactants used as amendments," Critical Reviews in Environmental Science and Technology 44(22), 2531-2576. DOI: 10.1080/10643389.2013.829764

Ahmad, M., Rajapaksha, A. U., Lim, J. E., Zhang, M., Bolan, N., Mohan, D., Vithanage, M., Lee, S. S., and Ok, Y. S. (2014). "Biochar as a sorbent for contaminant management in soil and water: A review," Chemosphere 99, 19-33. DOI: 10.1016/j.chemosphere.2013.10.071

Ali, H., Khan, E., and Sajad, M. A. (2013). "Phytoremediation of heavy metalsConcepts and applications," Chemosphere 91(7), 869-881. DOI:

10.1016/j.chemosphere.2013.01.075

Ali, N.A., Ater, M., Sunahara, G.I., and Robidoux, P.Y. (2004). "Phytotoxicity and bioaccumulation of copper and chromium using barley (Hordeumvulgare L.) in spiked artificial and natural forest soils," Ecotoxicology and Environmental Safety 57, 363-374. DOI: 10.1016/s0147-6513(03)00074-5

Antoniadis, V., Levizou, E., Shaheen, S. M., Ok, Y. S., Sebastian, A., Baum, C., Prasad, M. N. V., Wenzel, W. W., and Rinklebe, J. (2017). "Trace elements in the soil-plant interface: Phytoavailability, translocation, and phytoremediation - A review," EarthScience Reviews 171, 621-645. DOI: 10.1016/j.earscirev.2017.06.005

Arain, M. B., Kazi, T. G., Jamali, M. K., Afridi, H. I., Jalbani, N., Sarfraz, R. A., Baig, J. A., Kandhro, G. A., and Memon, M. A. (2008). "Time saving modified BCR sequential extraction procedure for the fraction of $\mathrm{Cd}, \mathrm{Cr}, \mathrm{Cu}, \mathrm{Ni}, \mathrm{Pb}$ and $\mathrm{Zn}$ in sediment samples of polluted lake," Journal of Hazardous Materials 160(1), 235-239. DOI: 10.1016/j.jhazmat.2008.02.092

Arslan, B., Djamgoz, M. B. A., and Akün, E. (2016). "Arsenic: A review on exposure pathways, accumulation, mobility and transmission into the human food chain," in: Reviews of Environmental Contamination and Toxicology, F. A. Gunther, and P. de Voogt (eds.), Springer, Cham, Switzerland, pp. 27-51.

Baker, A. J. M., and Brooks, R. R. (1989). "Terrestrial higher plants which hyperaccumulate metallic elements. A review of their distribution, ecology and phytochemistry," Biorecovery 1, 81-126.

Banks, M. K., Schwab, A. P., and Henderson, C. (2006). "Leaching and reduction of chromium in soil as affected by soil organic content and plants," Chemosphere 62(2), 255-264. DOI: 10.1016/j.chemosphere.2005.05.020 
Bhatti, H. N., Zaman, Q., Kausar, A., Noreen, S., and Iqbal, M. (2016). "Efficient remediation of $\mathrm{Zr}(\mathrm{IV})$ using citrus peel waste biomass: Kinetic, equilibrium and thermodynamic studies," Ecological Engineering 95, 216-228. DOI: 10.1016/j.ecoleng.2016.06.087

Burges, A., Alkorta, I., Epelde, L., and Garbisu, C. (2018). "From phytoremediation of soil contaminants to phytomanagement of ecosystem services in metal contaminated sites," International Journal of Phytoremediation 20(4), 384-397. DOI: 10.1080/15226514.2017.1365340

Carré, F., Caudeville, J., Bonnard, R., Bert, V., Boucard, P., and Ramel, M. (2017). "Soil contamination and human health: A major challenge for global soil security," in: Progress in Soil Science: Global Soil Security, D. J. Field, C. L. S. Morgan, and A. B. McBratney (eds.), Springer, Cham, Switzerland, pp. 275-295.

Chen, H., and Cutright, T. J. (2002). "The interactive effects of chelator, fertilizer, and rhizobacteria for enhancing phytoremediation of heavy metal contaminated soil," Journal of Soils and Sediments 2(4), 203-210. DOI: 10.1007/bf02991040

Choppala, G., Kunhikrishnan, A., Seshadri, B., Park, J. H., Bush, R., and Bolan, N. (2018). "Comparative sorption of chromium species as influenced by $\mathrm{pH}$, surface charge and organic matter content in contaminated soils," Journal of Geochemical Exploration 184(Part B), 255-260. DOI: 10.1016/j.gexplo.2016.07.012

Clemens, S., Palmgren, M. G., and Krämer, U. (2002). "A long way ahead: Understanding and engineering plant metal accumulation," Trends in Plant Science 7(7), 309-315. DOI: 10.1016/S1360-1385(02)02295-1

Conesa, H. M., Evangelou, M. W. H., Robinson, B. H., and Schulin, R. (2012). “A critical view of current state of phytotechnologies to remediate soils: Still a promising tool?," The Scientific World Journal 2012(173829), 1-10. DOI: 10.1100/2012/173829

Davies, Jr., F. T., Puryear, J. D., Newton, R. J., Egilla, J. N., and Saraiva Grossi, J. A. (2002). "Mycorrhizal fungi increase chromium uptake by sunflower plants: Influence on tissue mineral concentration, growth, and gas exchange," Journal of Plant Nutrition 25(11), 2389-2407. DOI: 10.1081/PLN-120014702

Ding, K., Liu, C., Tang, Y., Wang, S., Wei, X., Chao, Y., and Qiu, R. (2018). "Phytoremediation of heavy metal-contaminated soil in southern China," in: Twenty Years of Research and Development on Soil Pollution and Remediation in China, Y. Luo, and C. Tu (eds.), Springer, Singapore, pp. 375-387.

Egene, C. E., Van Poucke, R., Ok, Y. S., Meers, E., and Tack, F. M. G. (2018). "Impact of organic amendments (biochar, compost and peat) on $\mathrm{Cd}$ and $\mathrm{Zn}$ mobility and solubility in contaminated soil of the Campine region after three years," Science of The Total Environment 626, 195-202. DOI: 10.1016/j.scitotenv.2018.01.054

Ertani, A., Mietto, A., Borin, M., and Nardi, S. (2017). "Chromium in agricultural soils and crops: A review," Water, Air, \& Soil Pollution 228(5), Article Number 190. DOI: 10.1007/s11270-017-3356-y

Evangelou, M. W. H., Ebel, M., and Schaeffer, A. (2007). "Chelate assisted phytoextraction of heavy metals from soil. Effect, mechanism, toxicity, and fate of chelating agents," Chemosphere 68(6), 989-1003. DOI:

10.1016/j.chemosphere.2007.01.062

Gheju, M., and Balcu, I. (2017). "Assisted green remediation of chromium pollution," Journal of Environmental Management 203(Part 3), 920-924. DOI:

10.1016/j.jenvman.2017.04.094 
Ghosh, M., and Singh, S. P. (2005). "Comparative uptake and phytoextraction study of soil induced chromium by accumulator and high biomass weed species," Applied Ecology and Environmental Research 3(2), 67-79. DOI: 10.15666/aeer/0302_067079

Gu, X., Xie, J., Wang, X., and Evans, L. J. (2017). "A simple model to predict chromate partitioning in selected soils from China," Journal of Hazardous Materials 322(Part B), 421-429. DOI: 10.1016/j.jhazmat.2016.10.033

Gupta, A. K., Verma, S. K., Khan, K., and Verma, R. K. (2013). "Phytoremediation using aromatic plants: A sustainable approach for remediation of heavy metals polluted sites," Environmental Science \& Technology 47(18), 10115-10116. DOI: $10.1021 / \mathrm{es} 403469 \mathrm{c}$

Gustafsson, J. P., Persson, I., Oromieh, A. G., Van Schaik, J. W. J., Sjöstedt, C., and Kleja, D. B. (2014). "Chromium(III) complexation to natural organic matter: Mechanisms and modeling," Environmental Science \& Technology 48(3), 1753-1761. DOI: 10.1021/es404557e

Han, F. X., Su, Y., Sridhar, B. B. M., and Monts, D. L. (2004). "Distribution, transformation and bioavailability of trivalent and hexavalent chromium in contaminated soil," Plant and Soil 265(1-2), 243-252. DOI: 10.1007/s11104-0050975-7

Hasan, M., Kausar, D., Akhter, G., and Shah, M. H. (2018). "Evaluation of the mobility and pollution index of selected essential/toxic metals in paddy soil by sequential extraction method," Ecotoxicology and Environmental Safety 147, 283-291. DOI: 10.1016/j.ecoenv.2017.08.054

Hashemi, S. B., Momayezi, M., and Taleei, D. (2017). "Biochar effect on cadmium accumulation and phytoremediation factors by lavender (Lavandula stoechas L.)," Open Journal of Ecology 7(7), 447-459. DOI: 10.4236/oje.2017.77031

Hausladen, D. M., and Fendorf, S. (2017). "Hexavalent chromium generation within naturally structured soils and sediments," Environmental Science \& Technology 51(4), 2058-2067. DOI: 10.1021/acs.est.6b04039

He, Y. T., and Traina, S. J. (2005). "Cr(VI) reduction and immobilization by magnetite under alkaline $\mathrm{pH}$ conditions: The role of passivation," Environmental Science \& Technology 39(12), 4499-4504. DOI: 10.1021/es0483692

Herath, I., Iqbal, M. C. M., Al-Wabel, M. I., Abduljabbar, A., Ahmad, M., Usman, A. R. A., Ok, Y. S., and Vithanage, M. (2017). "Bioenergy-derived waste biochar for reducing mobility, bioavailability, and phytotoxicity of chromium in anthropized tannery soil," Journal of Soils and Sediments 17(3), 731-740. DOI: 10.1007/s11368015-1332-y

James, B. R., Petura, J. C., Vitale, R. J., and Mussoline, G. R. (1995). "Hexavalent chromium extraction from soils: A comparison of five methods," Environmental Science \& Technology 29(9), 2377-2381. DOI: 10.1021/es00009a033

Jardine, P. M., Stewart, M. A., Barnett, M. O., Basta, N. T., Brooks, S. C., Fendorf, S., and Mehlhorn, T. L. (2013). "Influence of soil geochemical and physical properties on chromium(VI) sorption and bioaccessibility," Environmental Science \& Technology 47(19), 11241-11248. DOI: 10.1021/es401611h

Kale, R. A., Lokhande, V. H., and Ade, A. B. (2015). "Investigation of chromium phytoremediation and tolerance capacity of a weed, Portulaca oleracea L. in a hydroponic system," Water and Environment Journal 29(2), 236-242. DOI: 10.1111/wej.12106 
Kumpiene, J., Lagerkvist, A., and Maurice, C. (2008). "Stabilization of As, Cr, Cu, Pb and $\mathrm{Zn}$ in soil using amendments - A review," Waste Management 28(1), 215-225. DOI: $10.1016 /$ j.wasman.2006.12.012

Langlois, C. L., and James, B. R. (2015). "Chromium oxidation-reduction chemistry at soil horizon interfaces defined by iron and manganese oxides," Soil Science Society of America Journal 79(5), 1329-1339. DOI: 10.2136/sssaj2014.12.0476

Lu S. Y., Du Y. Z., Zhong D. X., Zhao B., Li X. D., Xu M. X., Li Z., Luo Y. M., Yan J. H., and $\mathrm{Wu}$ L. H. (2012). "Comparison of trace element emissions from thermal treatments of heavy metal hyperaccumulators," Environmental Science \& technology 46(9), 5025-5031. DIO: 10.1021/es202616v

Ma, Y., Rajkumar, M., Zhang, C., and Freitas, H. (2016). "Beneficial role of bacterial endophytes in heavy metal phytoremediation," Journal of Environmental Management 174, 14-25. DOI: 10.1016/j.jenvman.2016.02.047

Mahar, A., Wang, P., Ali, A., Awasthi, M. K., Lahori, A. H., Wang, Q., Li, R., and Zhang, Z. (2016). "Challenges and opportunities in the phytoremediation of heavy metals contaminated soils: A review," Ecotoxicology and Environmental Safety 126, 111-121. DOI: 10.1016/j.ecoenv.2015.12.023

Mattina, M. I., Lannucci-Berger, W., Musante, C., and White, J. C. (2003). "Concurrent plant uptake of heavy metals and persistent organic pollutants from soil," Environmental Pollution 124(3), 375-378. DOI: 10.1016/S0269-7491(03)00060-5

Mendez, M. O., and Maier, R. M. (2008). "Phytoremediation of mine tailings in temperate and arid environments," Reviews in Environmental Science and Bio/Technology 7(1), 47-59. DOI: 10.1007/s11157-007-9125-4

Mohamed, R., Mustafa, A., and Erhayem, M. (2016). "Biosorption of Cr(VI) and Cu(II) by palm kernel powder and its potential application," International Journal of Environmental Science and Development 7(11), 788-792. DOI: 10.18178/ijesd.2016.7.11.881

Moon, D. H., Park, J.-W., Cheong, K. H., Hyun, S., Koutsospyros, A., Park, J.-H., and Ok, Y. S. (2013). "Stabilization of lead and copper contaminated firing range soil using calcined oyster shells and fly ash," Environmental Geochemistry and Health 35(6), 705-714. DOI: 10.1007/s10653-013-9528-9

Morel, J. L., Chenu, C., and Lorenz, K. (2015). "Ecosystem services provided by soils of urban, industrial, traffic, mining, and military areas (SUITMAs)," Journal of Soils and Sediments 15(8), 1659-1666. DOI: 10.1007/s11368-014-0926-0

Nirola, R., Megharaj, M., Subramanian, A., Thavamani, P., Ramadass, K., Aryal, R., and Saint, C. (2018). "Analysis of chromium status in the revegetated flora of a tannery waste site and microcosm studies using earthworm E. fetida," Environmental Science and Pollution Research 25(6), 5063-5070. DOI: 10.1007/s11356-017-0543-8

Njikam, E., and Schiewer, S. (2012). "Optimization and kinetic modeling of cadmium desorption from citrus peels: A process for biosorbent regeneration," Journal of Hazardous Materials 213-214, 242-248. DOI: 10.1016/j.jhazmat.2012.01.084

Panda, S. K., and Choudhury, S. (2005). "Chromium stress in plants," Brazilian Journal of Plant Physiology 17(1), 95-102. DOI: 10.1590/S1677-04202005000100008

Pandey, V. C., Bajpai, O., and Singh, N. (2016). "Energy crops in sustainable phytoremediation," Renewable and Sustainable Energy Reviews 54, 58-73. DOI: 10.1016/j.rser.2015.09.078 
Pichtel, J., and Bradway, D. J. (2008). "Conventional crops and organic amendments for $\mathrm{Pb}, \mathrm{Cd}$ and $\mathrm{Zn}$ treatment at a severely contaminated site," Bioresource Technology 99(5), 1242-1251. DOI: 10.1016/j.biortech.2007.02.042

Qu, C., Shi, W., Guo, J., Fang, B., Wang, S., Giesy, J. P., and Holm, P. E. (2016). "China's soil pollution control: Choices and challenges," Environmental Science \& Technology 50(24), 13181-13183. DOI: 10.1021/acs.est.6b05068

Rai, D., Eary, L. E., and Zachara, J. M. (1989). "Environmental chemistry of chromium," Science of the Total Environment 86(1-2), 15-23. DOI: 10.1016/00489697(89)90189-7

Sarwar, N., Imran, M., Shaheen, M. R., Ishaque, W., Kamran, M. A., Matloob, A., Rehim, A., and Hussain, S. (2017). "Phytoremediation strategies for soils contaminated with heavy metals: Modifications and future perspectives," Chemosphere 171, 710-721. DOI: 10.1016/j.chemosphere.2016.12.116

Seco-Reigosa, N., Bermúdez-Couso, A., Garrido-Rodríguez, B., Arias-Estévez, M., Fernández-Sanjurjo, M. J., Álvarez-Rodríguez, E., and Núñez-Delgado, A. (2013). "As $(\mathrm{V})$ retention on soils and forest by-products and other waste materials," Environmental Science and Pollution Research 20(9), 6574-6583. DOI: 10.1007/s11356-013-1730-x

Sengupta, A. K., Clifford, D., and Subramonian, S. (1986). "Chromate ion-exchange process at alkaline pH," Water Research 20(9), 1177-1184. DOI: 10.1016/00431354(86)90064-3

Shahandeh, H., and Hossner, L. R. (2000). "Plant screening for chromium phytoremediation," International Journal of Phytoremediation 2(1), 31-51. DOI: 10.1080/15226510008500029

Shahid, M., Shamshad, S., Rafiq, M., Khalid, S., Bibi, I., Niazi, N. K., Dumat, C., and Rashid, M. I. (2017). "Chromium speciation, bioavailability, uptake, toxicity and detoxification in soil-plant system: A review," Chemosphere 178, 513-533. DOI: 10.1016/j.chemosphere.2017.03.074

Shahid, M., Xiong, T., Masood, N., Leveque, T., Quenea, K., Austruy, A., Foucault, Y., and Dumat, C. (2014). "Influence of plant species and phosphorus amendments on metal speciation and bioavailability in a smelter impacted soil: A case study of foodchain contamination," Journal of Soils and Sediments 14(4), 655-665. DOI: 10.1007/s11368-013-0745-8

Sinha, V., Pakshirajan, K., and Chaturvedi, R. (2018). "Chromium tolerance, bioaccumulation and localization in plants: An overview," Journal of Environmental Management 206, 715-730. DOI: 10.1016/j.jenvman.2017.10.033

Tang, L., Luo, W., Chen, W., He, Z., Gurajala, H. K., Hamid, Y., Deng, M., and Yang, X. (2017). "Field crops (Ipomoea aquatica Forsk. and Brassica chinensis L.) for phytoremediation of cadmium and nitrate co-contaminated soils via rotation with Sedum alfredii Hance," Environmental Science and Pollution Research 24(23), 19293-19305. DOI: 10.1007/s11356-017-9146-7

Thijs, S., Sillen, W., Weyens, N., and Vangronsveld, J. (2017). "Phytoremediation: Stateof-the-art and a key role for the plant microbiome in future trends and research prospects," International Journal of Phytoremediation 19(1), 23-38. DOI: 10.1080/15226514.2016.1216076

Tokalığlu, Ş., Yilmaz, V., and Kartal, Ş. (2010). “An assessment on metal sources by multivariate analysis and speciation of metals in soil samples using the BCR 
sequential extraction procedure," CLEAN - Soil, Air, Water 38(8), 713-718. DOI: 10.1002/clen.201000025

Tzou, Y. M., Wang, M. K., and Loeppert, R. H. (2003). "Sorption of phosphate and $\mathrm{Cr}(\mathrm{VI})$ by $\mathrm{Fe}(\mathrm{III})$ and $\mathrm{Cr}(\mathrm{III})$ hydroxides," Archives of Environmental Contamination and Toxicology 44(4), 445-453. DOI: 10.1007/s00244-002-2090-6

USEPA 3060A (1996). "Alkaline digestion of hexavalent chromium," U.S. Environmental Protection Agency, Washington, DC, USA.

USEPA 7196A (1992). "Chromium, hexavalent (colorimetric)," U.S. Environmental Protection Agency, Washington, DC, USA.

Vargas, C., Pérez-Esteban, J., Escolástico, C., Masaguer, A., and Moliner, A. (2016). "Phytoremediation of $\mathrm{Cu}$ and $\mathrm{Zn}$ by vetiver grass in mine soils amended with humic acids," Environmental Science and Pollution Research 23(13), 13521-13530. DOI: 10.1007/s11356-016-6430-x

Velez, P. A., Talano, M. A., Paisio, C. E., Agostini, E., and González, P. S. (2017). "Synergistic effect of chickpea plants and Mesorhizobium as a natural system for chromium phytoremediation," Environmental Technology 38(17), 2164-2172. DOI: 10.1080/09593330.2016.1247198

Venkatachalam, P., Jayalakshmi, N., Geetha, N., Sahi, S. V., Sharma, N. C., Rene, E. R., Sarkar, S. K., and Favas, P. J. C. (2017). "Accumulation efficiency, genotoxicity, and antioxidant defense mechanisms in medicinal plant Acalypha indica L. under lead stress," Chemosphere 171, 544-553. DOI: 10.1016/j.chemosphere.2016.12.092

Verma, S. K., Trivedi, P., Gupta, A. K., and Verma, R. K. (2017). "Aromatic plantmicrobe associations: A sustainable approach for remediation of polluted soils," in: Agro-Environmental Sustainability, J. Singh, and G. Seneviratne (eds.), Springer, Cham, Switzerland, pp. 85-103.

Wang, M., Zhu, Y., Cheng, L., Andserson, B., Zhao, X., Wang, D., and Ding, A. (2018). "Review on utilization of biochar for metal-contaminated soil and sediment remediation," Journal of Environmental Sciences 63, 156-173. DOI: 10.1016/j.jes.2017.08.004

Wei, S., Li, Y., Zhou, Q., Srivastava, M., Chiu, S., Zhan, J., Wu, Z., and Sun, T. (2010). "Effect of fertilizer amendments on phytoremediation of Cd-contaminated soil by a newly discovered hyperaccumulator Solanum nigrum L.," Journal of Hazardous Materials 176(1-3), 269-273. DOI: 10.1016/j.jhazmat.2009.11.023

Yadav, S. K., Juwarkar, A. A., Kumar, G. P., Thawale, P. R., Singh, S. K., and Chakrabarti, T. (2009). "Bioaccumulation and phyto-translocation of arsenic, chromium and zinc by Jatropha curcas L.: Impact of dairy sludge and biofertilizer," Bioresource Technology 100(20), 4616-4622. DOI: 10.1016/j.biortech.2009.04.062

Yang, X. (2018). "Principles and technologies of phytoremediation for metalcontaminated soils: A review," in: Twenty Years of Research and Development on Soil Pollution and Remediation in China, Y. Luo, and C. Tu (eds.), Springer, Singapore, pp. 279-331.

Yin, W. J., Guo, Z. Z., Zhao, C. C., and Xu, J. T. (2019). "Removal of Cr(VI) from aqueous media by biochar derived from mixture biomass precursors of Acorus calamus Linn. and feather waste," Journal of Analytical and Applied Pyrolysis 140, 86-92. DOI: 10.1016/j.jaap.2019.04.024

Zayed, A. M., and Terry, N. (2003). "Chromium in the environment: Factors affecting biological remediation," Plant and Soil 249(1), 139-156. DOI:

10.1023/a:1022504826342 
Zhang, Y., Liu, J., Zhou, Y., Gong, T., Wang, J., and Ge, Y. (2013). "Enhanced phytoremediation of mixed heavy metal (mercury)-organic pollutants (trichloroethylene) with transgenic alfalfa co-expressing glutathione S-transferase and human P450 2E1," Journal of Hazardous Materials 260, 1100-1107. DOI: 10.1016/j.jhazmat.2013.06.065

Zhao, F.-J., Ma, Y., Zhu, Y.-G., Tang, Z., and McGrath, S. P. (2015). "Soil contamination in China: Current status and mitigation strategies," Environmental Science \& Technology 49(2), 750-759. DOI: 10.1021/es5047099

Zheljazkov, V. D., Craker, L. E., and Xing, B. (2006). "Effects of Cd, Pb, and Cu on growth and essential oil contents in dill, peppermint, and basil," Environmental and Experimental Botany 58(1-3), 9-16. DOI: 10.1016/j.envexpbot.2005.06.008

Article submitted: April 10, 2019; Peer review completed: November 17, 2019;

Revisions accepted: January 21, 2020; Published: March 30, 2020.

DOI: $10.15376 /$ biores.15.2.3545-3565 


\section{APPENDIX}

\section{SUPPLEMENTARY INFORMATION}

Table S1. Total and Tow Extractable Concentration of Toxic Metals in the Experimental Soils

\begin{tabular}{|c|c|c|c|c|c|c|c|c|}
\hline & & $\mathbf{C r}$ & $\mathbf{N i}$ & $\mathbf{C u}$ & $\mathbf{Z n}$ & $\mathbf{A s}$ & $\mathbf{C d}$ & $\mathbf{P b}$ \\
\hline \multirow{3}{*}{ T1 } & Total & $7,924 \pm 365.7$ & $32.6 \pm 2.4$ & $34.2 \pm 1.6$ & $534.1 \pm 63.6$ & $29.7 \pm 2.7$ & $0.9 \pm 0.1$ & $68.7 \pm 4.9$ \\
\cline { 2 - 8 } & water-soluble & $23.7 \pm 1.5$ & $0.17 \pm 0.03$ & $0.20 \pm 0.02$ & $0.54 \pm 0.23$ & $0.14 \pm 0.06$ & $0.00 \pm 0.00$ & $0.04 \pm 0.02$ \\
\cline { 2 - 9 } & acid-soluble & $35.2 \pm 4.5$ & $12.05 \pm 2.13$ & $0.42 \pm 0.07$ & $39.51 \pm 6.51$ & $0.15 \pm 0.01$ & $0.08 \pm 0.03$ & $0.32 \pm 0.08$ \\
\hline \multirow{3}{*}{ T2 } & total & $8,400 \pm 126.4$ & $33.1 \pm 1.6$ & $51.5 \pm 3.2$ & $612.7 \pm 30.1$ & $34.2 \pm 2.0$ & $1.0 \pm 0.0$ & $73.5 \pm 3.1$ \\
\cline { 2 - 9 } & water-soluble & $32.1 \pm 2.6$ & $0.03 \pm 0.01$ & $0.02 \pm 0.01$ & $0.33 \pm 0.26$ & $0.08 \pm 0.01$ & $0.00 \pm 0.00$ & $0.02 \pm 0.02$ \\
\cline { 2 - 9 } & acid-soluble & $46.9 \pm 5.0$ & $14.54 \pm 3.32$ & $0.10 \pm 0.05$ & $38.41 \pm 0.63$ & $0.12 \pm 0.00$ & $0.05 \pm 0.00$ & $0.19 \pm 0.02$ \\
\hline \multirow{3}{*}{ T3 } & total & $8,740 \pm 264.0$ & $32.8 \pm 0.3$ & $36.0 \pm 0.8$ & $654.0 \pm 10.8$ & $33.0 \pm 2.0$ & $1.0 \pm 0.0$ & $78.1 \pm 1.3$ \\
\cline { 2 - 9 } & water-soluble & $44.6 \pm 4.1$ & $0.06 \pm 0.01$ & $0.10 \pm 0.01$ & $0.54 \pm 0.13$ & $0.09 \pm 0.03$ & $0.00 \pm 0.00$ & $0.04 \pm 0.01$ \\
\cline { 2 - 9 } & acid-soluble & $28.2 \pm 1.6$ & $14.96 \pm 1.57$ & $0.41 \pm 0.03$ & $54.59 \pm 6.36$ & $0.10 \pm 0.00$ & $0.06 \pm 0.00$ & $0.26 \pm 0.02$ \\
\hline
\end{tabular}

$(\mathrm{n}=3)$; values represent mean \pm S.D (mg/kg dry mass) 